\title{
Pengaruh Word Of Mouth dan Switching Cost Terhadap Keputusan Pembelian dan Loyalitas
}

\author{
Iha Haryani Hatta ${ }^{1 *}$, Setiarini ${ }^{2}$ \\ Fakultas Ekonomi dan Bisnis Universitas Pancasila, Jakarta \\ Jalan Lenteng Agung, Srengseng Sawah, Jakarta Selatan \\ *Email : iha.haryani@yahoo.com
}

\begin{tabular}{|c|c|}
\hline Artikel Info & ABSTRAK \\
\hline $\begin{array}{l}\text { Received: } \\
21 \text { Februari } 2018 \\
\text { Revised: } \\
8 \text { Maret } 2018 \text {, } \\
\text { Accepted: } \\
11 \text { April } 2018\end{array}$ & $\begin{array}{l}\text { Pengaruh word of mouth dan switching cost terhadap keputusan pembelian dan loyalitas. } \\
\text { Tujuan penelitian ini adalah ingin mengetahui pengaruh word of mouth dan switching cost } \\
\text { terhadap keputusan pembelian dan loyalitas, serta pengaruh keputusan pembelian terhadap } \\
\text { loyalitas . Populasi penelitian ini adalah pelanggan Meat Me Café \& Butchery di Jakarta. } \\
\text { Responden sebanyak } 200 \text { pelanggan yang dipilih secara acak. Data diolah dengan SEM, }\end{array}$ \\
\hline & $\begin{array}{l}\text { berpengaruh masing-masing terhadap keputusan pembelian dan loyalitas, serta keputusan } \\
\text { memberian berpengaruh terhadap loyalitas. Jalur word of mouth dan switching cost } \\
\text { meman yang sama terhadap keputusan pembelian, dan loyalitas. }\end{array}$ \\
\hline
\end{tabular}

Kata Kunci: Word of Mouth, Switching Cost, Keputusan Pembelian, Loyalitas

\section{Influence of Word of Mouth and Switching Cost on Purchasing Decision and Loyalty}

\section{ABSTRACT}

The reciprocal of WOM (word of mouth) \& switching cost into purchasing and loyality. The purpose of research The affect WOM and switching cost of the decision to purchase \& loyalty; The affect the decision to purchase of loyalty. The population this research are 200 Meat Me Café \& Butchery's customers in jakarta who were randomly selected by mixed data with SEM, AMOS21 program. The results of research explained that WOM and switching cost are influential decision to buy \& loyalty, and the decision to buy influences loyalty. The WOM \& switching cost substantiate same as purchase of the decision, and loyalty.

Key word: Word of Mouth, Switching cost, Purchasing Decision, Loyalty.

How to Cite:

Hatta, I. H., \& Setiarini. (2018). Pengaruh Word Of Mouth dan Switching Cost Terhadap Keputusan Pembelian dan Loyalitas. Jurnal Ilmiah Manajemen dan Bisnis, 19(1), 32-40. https://doi.org/10.30596/jimb.v19i1.1728. 


\section{PENDAHULUAN}

Saat ini, banyak perusahaan yang menawarkan produk yang bersaing baik produk manufaktur maupun jasa seperti kuliner. Meat Me Café \& Butchery sebagai usaha dalam industri kuliner yang tidak lepas dari fenomena perubahan intensitas persaingan untuk mendapatkan hati pelanggan. Meat Me Café \& Butchery adalah restoran steak yang menawarkan berbagai jenis daging dengan fasilitas toko daging di dalam restoran. Restoran tersebut menawarkan daging berdasarkan negara asal (Amerika Serikat, Jepang, Australia dan Selandia Baru), pemotongan (Striploin, Tenderloin, Rib Eye, Porter House dan T-Bone) dan oleh perbedaan kelas/marbling.

Setiap perusahaan perlu membuat strategi pemasaran yang tepat dan mengacu pada consumer oriented (memenuhi kebutuhan dan keinginan konsumen), sehingga produk atau jasa tersebut akan diterima oleh konsumen, dan dapat bersaing di masa sekarang dan akan datang yang akan mempengaruhi keputusan pembelian dari konsumen (Mariaji dan Yuniati, 2014)). Sementara itu (Chen, et al., 2016) menerangkan bahwa keputusan pembelian dapat menciptakan loyalitas konsumen. Hal tersebut penting bagi suatu perusahaan, karena loyalitas konsumen dapat mendukung kelangsungan hidup suatu perusahaan. Perusahaan juga perlu meningkatkan pemahaman tentang word of mouth dan switching cost (biaya beralih). Meskipun berkembang pesatnya teknologi informasi saat ini, word of mouth dapat memberikan berbagai informasi kepada masyarakat secara menarik, memberi keuntungan, dan sesuai dengan harapan. Sementara itu menurut (Tjiptono, 2014), pemahaman mengenai switching cost sangat penting dikarenakan dampak signifikannya pada perilaku pembelian ulang, strategi pemasaran yang harus diterapkan dan struktur industri persaingan.

Berdasarkan hasil penelitian terdahulu diperoleh informasi bahwa hubungan variabel word of mouth, switching cost, keputusan pembelian, dan loyalitas pelanggan tidak konsisten. Hasil penelitian (Nugraha et al., 2015) menemukan bahwa word of mouth ber pengaruh terhadap keputusan pembelian. Tetapi hasil penelitian(Yunita dan Haryanto, 2012) menjelaskan bahwa word of mouth tidak berpengaruh terhadap keputusan pembelian. Sementara itu,hasil penelitian Caruana, (2004) bahwa Switchng Cost berpengaruh terhadap loyalitas konsumen. Tetapi hasil penelitian(Ting, 2014)) menjelaskan bahwa bila tingkat kepuasaan pelanggan tinggi atau rendah, maka tidak ada pengaruh antara switching cost dan pembelian ulang.

Kotler, (2002) menjelaskan bahwa word of mouth (WOM) atau komunikasi dari mulut ke mulut adalah proses komunikasi berupa pemberian rekomendasi kepada individu maupun kelompok tentang suatu produk atau jasa. Word of mouth dapat menjadi promosi dari mulut ke mulut, yang hanya memerlukan biaya yang sangat kecil atau bahkan tidak memerlukan biaya sama sekali. Menurut (Rangkuti, 2015), word of mouth dapat memasarkan suatu produk dan jasa dengan virus marketing melalui pembicaraan, promosi, dan rekomendasi dari pelanggan tentang produk dan jasa kepada orang lain secara antusias dan sukarela. Word of mouth mampu menyebar begitu cepat bila pelanggan atau individu yang menyebarkannya memiliki jaringan yang luas

Menurut Whitten dan Wakefield, (2006) switching cost menunjukkan suatu resiko, investasi, dan kehilangan pelanggan dengan perpindahan konsumen dari suatu merek tertentu ke merek lain atau dari penyedia jasa tertentu ke penyedia jasa lainnya. Beberapa 
studi menjelaskan bahwa switching cost antara lain kehilangan financial, waktu, psikologis dan hubungan yang dirasakan konsumen ketika berpindah ke penyedia lainnya. Switching cost biasanya tidak keluar langsung setelah berpindah ke penyedia yang lain, tetapi biasanya pelanggan merasakannya setelah beberapa lama mereka berpindah, dalam pengambilan keputusan, semua aspek pengaruh dan kognisi dilibatkan termasuk pengetahuan, arti, kepercayaan yang diaktif kan dari ingatan serta proses perhatian dan pemahaman yang terlibat dalam penerje mahan informasi baru di lingkungan. Menurut Kotler dan Keller, (2012), proses keputusan pembelian yang spesifik terdiri dari urutan kejadian sebagai berikut: pengenalan masalah kebutuhan, pencarian informasi, evaluasi alter natif, keputusan pembelian dan perilaku pasca pembelian. Perilaku pembelian kembali oleh konsumen terhadap suatu produk dapat men jadi aset yang bernilai strategic. Menurut Amin, (2008) kelekatan pelanggan pada suatu merek, toko, pabrikan, pemberi jasa, atau entitas lain merupakan tanggapan yang baik dan sikap yang menguntungkan seperti pem belian ulang. Berdasarkan definisi tersebut, dapat disimpulkan bahwa ada unsur perilaku dan sikap dalam loyalitas pelanggan.

Pada penelitian ini variabel bebas (independen) yaitu variabel word of mouth, dan switching cost, sedangkan variabel terikat (dependen) yaitu variabel keputusan pembelian dan loyalitas pelanggan. Hubungan variabel tersebut dijabarkan pada 5 hipotesa alternative, yaitu H1: Word of mouth berpengaruh terhadap keputusan pembelian, H2: Switching cost berpengaruh terhadap keputusan pembelian, H3: Word of mouth berpengaruh terhadap loyalitas pelanggan, H4: Switching cost berpengaruh terhadap loyalitas pelanggan, dan H5: Keputusan pembelian berpengaruh terhadap loyalitas pelanggan

\section{METODE}

Penelitian ini menggunakan data primer, sumber data diperoleh secara langsung dari sumber aslinya berupa wawancara. Populasi penelitian ini adalah konsumen yang mengunjungi atau berbelanja produk makanan di Meat Me Café \& Butchery. Penelitian ini menggunakan 200 responden yang dipilih secara acak. Pengumpulan data dilakukan dengan membagikan kuesioner kepada pelanggan di Meat Me Café \& Butchery. Kuesioner terdiri dari pernyataan tertutup dengan alternative jawaban sesuai skala Likert. Ada 5 alternatif jawaban, yaitu 1 (sangat tidak setuju), 2 (tidak setuju), 3 (netral), 4 (setuju), dan 5 (sangat setuju). Sebelumnya data diolah, dilakukan uji validitas dan reliabilitas. Menurut Sugiyono, (2012) menyatakan bahwa valid berarti istrumen tersebut dapat digunakan untuk mengukur apa yang seharusnya diukur. Dasar pengambilan keputusan untuk menguji validitas butir angket adalah : $\mathrm{R}_{\text {hitung }}>\mathrm{r}_{\text {tabel, }}$ maka variabel tersebut valid. Sedangkan uji reliabilitas menyatakan bahwa apabila instrument yang digunakan beberapa kali untuk mengukur objek yang sama akan menghasilkan data yang sama. Reliabilitas adalah derajat konsistensi data dalam interval waktu tertentu. Data yang diujikan reliabilitasnya adalah data yang mewakili variabel menggunakan metode Cronbach Alpha, nilai yang didapat dari pengujian ini harus lebih besar dari 0,7. Kemudian data dianalisis Structural Equation Modelling (SEM) dengan program AMOS dan menggunakan SPSS dalam melakukan analisis deskriptif yang berupa nilai rata-rata yang dilakukan untuk memberi penilaian pada variabel yang diamati. Penilaian dengan 
rumus bahwa (nilai tertinggi (5) - nilai terendah (1))/ jumlah kelas (5). Sehingga kategori penilaian adalah sangat rendah $(1,00$ - 1,80), rendah $(1,81-2,60)$, cukup $(2,61$ $3,40)$, tinggi $(3,41-4,20)$, dan sangat tinggi (4,21-5,00). Sedangkan SEM menurut (Mahfud, 2013) mampu menguji model penelitian yang kompleks secara simultan dan menganalisis variabel yang tidak dapat diukur langsung (unobserved variables) dan memperhitungkan kesalahan pengukuruannya. Menurut (Wardoyo, 2012), salah satu program SEM berbasis covariance adalah AMOS. Menurut (Newbold, 1992) covariances menunjukkan hubungan linear yang terjadi antara dua variabel, yaitu $\mathrm{X}$ dan Y. Jika suatu variabel memiliki hubungan linear positif, maka kovariannya adalah positif. Jika hubungan antara X dan Y berlawanan, maka kovariannya adalah negatif. Jika tidak terdapat hubungan antara dua variabel $\mathrm{X}$ dan Y, maka kovariannya adalah nol. Dapat diperoleh hasil uji reliablitas, dan validitas, serta uji t. Variabel dikatakan reliabilitas, bila construct reliability $(\mathrm{CR}) \geq 0,70$ dan nilai variance extracted $(\mathrm{VE}) \geq 0,50$. Indikator dari variabel dikatakan valid, bila nilai Standardized Loading Factor (SLF) $\geq 0,50$. Sedangkan bila $\mathrm{t}$ hitung $>1,96$ dengan nilai $\mathrm{p}$ sebesar $* * *(0,000)<0,05$, maka hipotesis 0 diterima. Artinya tidak ada pengaruh antar 2 variabel.

\section{HASIL}

Karakteristik 200 responden adalah kebanyakan wanita (57,5\%), kebanyakan belum menikah $(51,0 \%)$, mayoritas usianya adalah 21 - 30 tahun $(48,0 \%)$, mayoritas pen didikannya adalah S1 (47,5\%), dan kebanya kan responden adalah karyawan (34,0\%). Berdasarkan nilai construct reliability $(\mathrm{CR}) \geq$ 0,70 dan nilai variance extracted $(\mathrm{VE}) \geq 0,50$, serta nilai Standardized Loading Factor (SLF) $\geq 0,50$, maka variabel Word of Mouth, Switching Cost, Keputusan Pembelian, dan Loyalitas dapat dikatakan reliabel. Sedangkan 31 indikator yang mendukung variabel tersebut yang terdiri dari 8 indikator Word of Mouth, 8 indikator Switching Cost, 8 indikator Keputusan Pembelian, dan 7 indikator Loyalitas dapat dikatakan valid. Variabel word of mouth memiliki nilai rata-rata sebesar 4.09. Artinya, 3 indikatornya yang dominan (WOM7, WOM8, dan WOM5) yaitu bercerita kepada orang lain tentang citra rasa yang tinggi, sebagai restoran yang baik, serta kualitas pelayanan pemesanan yang baik, dapat mendukung minat responden yang tinggi untuk melakukan word of mouth tentang restoran "Meat Me Cafe \& Butchery". Variabel switching cost memiliki nilai ratarata sebesar 3.85. Artinya, 4 indikatornya yang dominan (SC3, SC7, SC1, dan SC8) yaitu bersedia untuk mengeluarkan biaya sosialisasi restoran baru, kehilangan benefit jika beralih ke restoran lain, mengeluarkan biaya untuk berlangganan restoran baru, serta mengevaluasi biaya ketika saya akan berpindah ke restoran lain, dapat menjelaskan minat responden yang tinggi untuk melakukan switching cost pada restoran "Meat Me Cafe \& Butchery". Variabel keputusan pembelian memiliki nilai rata-rata sebesar 4.00. Artinya, 3 indikatornya yang dominan (KP3, KP4, dan KP8) yaitu memiliki tempat yang nyaman, produk tersedia ketika konsumen menginginkannya, serta sudah lama dicari, dapat menjelaskan minat responden yang tinggi untuk melakukan keputusan pembelian pada restoran "Meat Me Cafe \& Butchery". Variabel loyalitas memiliki nilai rata-rata sebesar 4.01. Artinya, 3 indikatornya yang dominan (LOY1, LOY5, dan LOY6) yaitu pilihan terbaik, mudah dicari dan cepat dalam pelayanan, serta pilihan utama, dapat menjelaskan minat responden yang tinggi 


\section{Published April 2018 \\ JURNAL ILMIAH MANAJEMEN dan BISNIS \\ ISSN 1693-7619 (print) | ISSN 2580-4170 (online), http://jurnal.umsu.ac.id/index.php/mbisnis}

untuk loyal pada restoran "Meat Me Cafe \& Butchery".

\section{PEMBAHASAN}

Variabel bebas (word of mouth dan switching cost) dan tidak bebas (keputusan pembelian dan loyalitas) pada penelitian ini membentuk 2 persamaan regresi berganda, yaitu:

$\mathrm{KP}=0,57 \mathrm{WOM}+0,76 \mathrm{SC}+0,10$

$\mathrm{LOY}=0,32 \mathrm{WOM}+0,21 \mathrm{SC}+0,56 \mathrm{KP}+0,08$

Dimana: KP $=$ Keputusan Pembelian, LOY = Loyalitas, $\mathrm{WOM}=$ Word of Mouth, dan $\mathrm{SC}=$ Switching Cost
Variabel word of mouth dapat memberikan sumbangan sebesar 0,57 unit satuan dan variabel switching cost dapat memberikan sumbangan sebesar 0,67 unit satuan terhadap variabel keputusan pembelian. Sedangkan variabel word of mouth dapat memberikan sumbangan sebesar 0,32 unit satuan, variabel switching cost dapat memberikan sumbangan sebesar 0,21 unit satuan, serta variabel keputusan pembelian dapat memberikan sumbangan sebesar 0,56 unit satuan terhadap variabel loyalitas. Model variabel tersebut dinyatakan dalam Gambar 1.

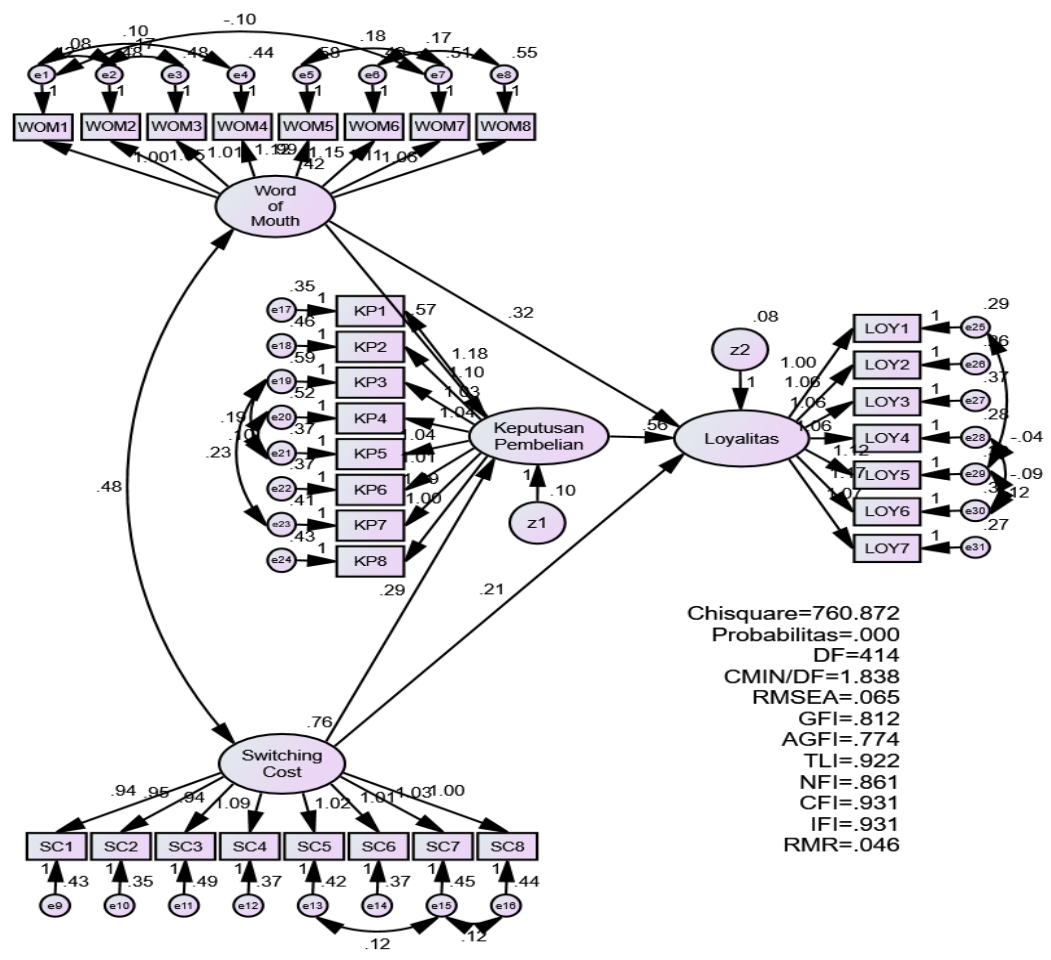

Gambar 1. Full Model Struktural

Berdasarkan CMIN, TLI, CFI, RMESA yang dijabarkan pada Tabel 1 maka dapat dikatakan bahwa persamaan/model diatas adalah cocok (good of fit). Hal tersebut dapat menunjukkan bahwa data observasi sudah sesuai atau konsisten dengan teori atau model yang akan diuji meskipun masih terdapat nilai poor fit tetapi masih memenunuhi ketentuan, sehingga model yang diajukan dinilai masih 
baik dan dapat diterima sebagai model yang sesuai pada penelitian ini.

Tabel 1. Uji Goodness of Fit (GOF)

\begin{tabular}{|c|c|c|c|c|}
\hline & Goodness of Fit Index & Cut off Value & $\begin{array}{l}\text { Nilai Pada } \\
\text { Model }\end{array}$ & Keterangan \\
\hline 1. & Chi-Square $\left(x^{2}\right)$ & Semakin kecil semakin baik & 760.862 & Poor Fit \\
\hline 2. & CMIN/DF & $<2.0$ & 1.838 & Good Fit \\
\hline 3. & Probability level & $p \geq 0.05$ & 0.000 & Poor Fit \\
\hline 4. & GFI & $\begin{array}{l}\text { GFI } \geq 0.90 \text { (Good Fit) } \\
0.80 \leq \mathrm{GFI} \leq 0.90 \text { (Marginal Fit) }\end{array}$ & 0.812 & Marginal Fit \\
\hline 5. & AGFI & $\begin{array}{l}\text { AGFI } \geq 0.90 \text { (Good Fit) } \\
0.80 \leq \text { AGFI } \leq 0.90 \text { (Marginal Fit) }\end{array}$ & 0.774 & Poor Fit \\
\hline 6. & TLI & $\begin{array}{l}\text { TLI } \geq 0.90 \text { (Good Fit) } \\
0.80 \leq \text { TLI } \leq 0.90 \text { (Marginal Fit) }\end{array}$ & 0.922 & Good Fit \\
\hline 7. & $\mathrm{CFI}$ & $\begin{array}{l}\text { GFI } \geq 0.90 \text { (Good Fit) } \\
0.80 \leq \text { GFI } \leq 0.90 \text { (Marginal Fit) }\end{array}$ & 0.931 & Good Fit \\
\hline 8. & RMESA & $\begin{array}{l}\text { RMSEA } \leq 0.05 \text { (Close Fit) } \\
\text { RMSEA } \leq 0.08 \text { (Good Fit) }\end{array}$ & 0.065 & Good Fit \\
\hline
\end{tabular}

Sumber : Hasil Pengolahan Data

Berdasarkan uji t, maka akan diperoleh $t_{\text {hitung }}$ yang lebih besar dari t tabel dengan $\alpha=0,05$, yang dijabarkan pada Tabel 2 .

Tabel 2. Hasil Pengujian

\begin{tabular}{|c|c|c|c|c|}
\hline & Hipotesis & t hitung & t tabel $(\alpha=0,05)$ & Hasil \\
\hline $\mathrm{H}_{1}$ & $\begin{array}{l}\text { Word of Mouth berpengaruh signifikan } \\
\text { dan positif terhadap variabel } \\
\text { Keputusan Pembelian }\end{array}$ & 4,378 & 1,96 & $\mathrm{H} 1$ diterima \\
\hline $\mathrm{H}_{2}$ & $\begin{array}{l}\text { Switching Cost berpengaruh signifikan } \\
\text { dan positif terhadap variabel } \\
\text { Keputusan Pembelian }\end{array}$ & 3.280 & 1,96 & H2 diterima \\
\hline $\mathrm{H}_{3}$ & $\begin{array}{l}\text { Word of Mouth berpengaruh signifikan } \\
\text { dan positif terhadap variabel Loyalitas }\end{array}$ & 2.366 & 1,96 & H3 diterima \\
\hline $\mathrm{H}_{4}$ & $\begin{array}{l}\text { Switching Cost berpengaruh signifikan } \\
\text { dan positif terhadap variabel Loyalitas }\end{array}$ & 2.669 & 1,96 & H4 diterima \\
\hline $\mathrm{H}_{5}$ & $\begin{array}{l}\text { Keputusan Pembelian berpengaruh } \\
\text { signifikan dan positif terhadap variabel } \\
\text { Loyalitas }\end{array}$ & 4.440 & 1,96 & H5 diterima \\
\hline
\end{tabular}

Pada Tabel 2 memperlihatkan bahwa Hipotesis 1 dapat diterima, karena nilai $t_{\text {hitung }}$ sebesar 4,378 > 1,96, artinya bahwa word of mouth berpengaruh terhadap keputusan pembelian. Kenyataan ini menunjukkan bahwa keragaman nilai indikator variabel word of mouth dan keputusan pembelian dapat menjelaskan hubungan 2 variabel tersebut. Hasil penelitian ini juga tidak sesuai dengan hasil penelitian (Xiao, et al., 2005) bahwa ada ketidakpastian antara hubungan switching cost dan keputusan pembelian. Hipotesis 2 dapat diterima, karena nilai thitung sebesar 3,280 > 1,96, artinya bahwa switching cost berpengaruh terhadap keputusan pembelian. Kenyataan ini menunjukkan 
bahwa keragaman nilai indikator variabel switching cost dan keputusan pembelian dapat menjelaskan hubungan 2 variabel tersebut. Hipotesis 3 diterima, karena nilai $t_{\text {hitung }}$ sebesar $2.366>1,96$, artinya bahwa word of mouth berpengaruh terhadap loyalitas. Kenyataan ini menunjukkan bahwa keraga man nilai indikator variabel word of mouth dan loyalitas dapat menjelaskan hubungan 2 variabel tersebut. Hasil penelitian ini sesuai dengan hasil penelitian Riduan (2010), (Yusfita dan Yulianto, 2018). Hipotesis 4 diterima, karena nilai $t_{\text {hitung }}$ sebesar 2,669 > 1,96, artinya switching cost berpengaruh terhadap loyalitas. Kenyataan ini menunjukkan bahwa keragaman nilai indikator variabel switching cost dan loyalitas dapat menjelas kan hubungan 2 variabel tersebut. H5 diterima, karena nilai t hitung sebesar 2,366 > 1,96 artinya keputusan pembelian berpengaruh terhadap loyalitas. Kenyataan ini menunjukkan bahwa kera-gaman nilai indikator variabel keputusan pembelian dan loyalitas dapat menjelaskan hubungan 2 variabel tersebut.

Pengaruh langsung dan tidak langsung antara variabel penelitian ini dijabarkan pada Tabel 3, terlihat bahwa pengaruh langsung variabel word of mouth terhadap loyalitas sebesar 0,318 dan pengaruh tidak langsungnya melalui variabel keputusan pembelian sebesar 0,57 x $0,56=0,320$, sehingga pengaruh totalnya sebesar $0,318+0,320=$ 0,638 . Variabel keputusan pembelian meningkatkan pengaruh atau menjadi variabel intervening bagi hubungan variabel word of mouth dan loyalitas. Dari tabel 3 terlihat juga bahwa pengaruh langsung variabel switching cost terhadap loyalitas sebesar 0,21 dan pengaruh tidak langsungnya melalui variabel keputusan pembelian sebesar $0,76 \times 0,56=$ 0,43 , sehingga pengaruh totalnya sebesar 0,21 $+0,43=0,64$. variabel keputusan pembelian meningkatkan pengaruh atau menjadi variabel intervening bagi hubungan variabel switching cost dan loyalitas.

Tabel 3. Pengaruh Langsung dan Tidak Langsung

\begin{tabular}{|c|c|c|c|c|}
\hline Hubungan & $\begin{array}{l}\text { Pengaruh } \\
\text { Langsung }\end{array}$ & $\begin{array}{l}\text { Pengaruh } \\
\text { Langsung }\end{array}$ & Tidak & $\begin{array}{l}\text { Pengaruh } \\
\text { Total }\end{array}$ \\
\hline WOM, KP, LOY & 0,32 & 0,32 & & 0,64 \\
\hline SC, KP, LOY & 0,21 & 0,43 & & 0,64 \\
\hline
\end{tabular}

Sumber: hasil pengolahan data

Tabel 3 dapat dikatakan bahwa 2 jalur hubungan yang ada yaitu jalur Word of Mouth, Keputusan Pembelian, dan Loyalitas memiliki pengaruh total yang sama dengan jalur Switching Cost, Keputusan Pembelian, dan Loyalitas. Variabel Word of Mouth dan Switching Cost merupakan faktor keputusan pembelian yang mempengaruhi Loyalitas.

\section{SIMPULAN}

Variabel word of mouth berpengaruh signifikan terhadap variabel keputusan pembelian. Variabel Switching Cost berpengaruh signifikan terhadap keputusan pembelian. Promosi dari mulut ke mulut dan peralihan biaya konsumen dari suatu restoran ke restoran yang lain masing-masing akan menimbulkan keinginan konsumen untuk melakukan pembelian terhadap restoran Meat Me Café \& Butchery. Sedangkan variabel word of mouth berpengaruh signifikan terhadap variabel loyalitas. Variabel switching cost berpengaruh signifikan terhadap variabel keputusan pembelian. Promosi dari mulut ke 
mulut dan peralihan biaya konsumen dari suatu restoran ke restoran yang lain dapat membuat konsumen akan berkunjung secara terus menerus bahkan terbentuknya dari diri konsumen loyal terhadap restoran tersebut. Sementara itu variabel keputusan pembelian berpengaruh signifikan terhadap Loyalitas Adanya keinginan untuk melakukan pembelian dan merasakan kepuasan akan menimbulkan pembelian secara terus-menerus bahkan sikap loyal. Implikasi penelitian ini adalah kegiatan word of mouth dan switching cost bila dilakukan secara bersama-sama akan memperkuat tingkat keputusan pembelian yang akhirnya akan membentuk sikap loyalitas pelanggan terhadap suatu produk. Restoran "Meat Me Cafe \& Butchery" perlu meningkatkan partisipasi pelanggan untuk bercerita kepada orang lain tentang citra rasa yang tinggi, sebagai restoran yang baik, serta kualitas pelayanan pemesanan yang baik, yang dapat mendukung minat responden yang tinggi untuk melakukan word of mouth tentang restoran "Meat Me Cafe \& Butchery" yang akhirnya meningkatkan keputusan pembelian dan loyalitas. Restoran "Meat Me Cafe \& Butchery" juga perlu meningkatkan kesadaran pelanggan bahwa pelanggan akan mengeluarkan biaya sosialisasi restoran baru, kehilangan benefit, mengeluarkan biaya untuk berlangganan restoran baru, serta mengevaluasi biaya ketika berpindah ke restoran lain, yang akhirnya akan meningkatkan keputusan pembelian dan loyalitas.

\section{RERERENSI}

Caruana, A. (2004). The impact of switching costs on customer loyalty : A study among corporate customers of mobile telephony. Journal of Targeting, Measurement and Analysis for Marketing, 12(3), 256-268.

Amin, W. T. (2008). Manajemen Audit Suatu
Pengantar. Jakarta: Rineka Cipta.

Chen, Y., Chen, T., \& Lin, C. (2016). The Analyses of Purchasing Decisions and Brand Loyalty for Smartphone Consumers. Journal of Social Science, 108-116.

https://doi.org/10.4236/jss.2016.47018

Kotler, P. and Keller, K. . (2012). Marketing

Management (14th ed.). US: Pearsons Education.

Kotler, P. (2002). Manajemen Pemasaran. Jakarta: Penerbit Erlangga.

Mahfud, S, D. R. (2013). Analisis SEM-PLS dengan WarpPLS 3.0. Yogyakarta: Andi Offset.

Mariaji, W., \& Yuniati, T. (2014). Pengaruh Perilaku Konsumen Terhadap Keputusan Pembelian Compact Disc (Cd) Di Surabaya. Jurnal Ilmu \& Riset Manajemen, 3(8), 1-15.

Newbold, P. (1992). Statistics for Business and Economics (Third Edit). USA: Prentice Hall.

Nugraha, F. A. A., Suharyono, \& Kusumawati, A. (2015). Pengaruh Word Of Mouth Terhadap Keputusan Pembelian Dan Kepuasan Konsumen (Studi pada Konsumen Kober Mie Setan jalan Simpang Soekarno-Hatta nomor 12 Malang ). Jurnal Administrasi Bisnis (JAB), 22(1), 1-7.

Rangkuti, F. (2015). Spritual Leadership in Business. Jakarta: PT. Gramedia Pustaka Utama.

Sugiyono. (2012). Metodologi Penelitian. Bandung: Alfabeta.

Ting, S. (2014). The Relationship between Customers , Switching Cost and Repurchase Intention: The Moderating Role of Satisfaction. Journal of Service Science and Management, 313-322. https://doi.org/10.4236/jssm.2014.74028 Tjiptono, F. (2014). Pemasaran Jasa. Jakarta: 
Gramedia.

Wardoyo, S. H. dan P. (2012). Structural Equation Modeling. Untuk Penelitian Manajemen Menggunakan AMOS 18.00. Bekasi: Intermedia Personalia Utama.

Whitten, D. and Wakefield, R. (2006). Measuring Switching Costs in IT Outsourching Services. Journal of Strategic Information Systems, 15. 219248.

http://dx.doi.org/10.1016/j.jsis.2005,11. 002

Xiao, B., Feng, Y., \& Roche, E. (2005). Uncertain Switching Costs and Purchase Decisions, 179-196.

Yunita, A., \& Haryanto, J. O. (2012). Pengaruh Word of Mouth, Iklan dan Atribut Produk terhadap Keputusan Pembelian dan Loyalitas Konsumen. Jurnal Manajemen Teknologi, 11(1), 75-95.

Yusfita N., \& Yulianto, E. (2018). Pengaruh Experiential Marketing Dan Word Of Mouth Terhadap Loyalitas Pelanggan. Jurnal Administrasi Bisnis (JAB), 57(1), 46-52. 